\title{
The Audience of Latin Historical Works in the First Century BCE in Light of Geographical Descriptions
}

\begin{abstract}
Liv. 9.2.6-8
Duae ad Luceriam ferebant viae, altera praeter oram superi maris, patens apertaque sed quanto tutior tanto fere longior, altera per furculas Caudinas, brevior; sed ita natus locus est: saltus duo alti angusti silvosique sunt montibus circa perpetuis inter se iuncti; iacet inter eos satis patens clausus in medio campus herbidus aquosusque, per quem medium iter est; sed antequam venias ad eum, intrandae primae primae angustiae sunt, et aut eadem qua te insinuaveris retro via repetenda aut, si ire porro pergas, per alium saltum artiorem impeditioremque, evadendum.

There were two roads to Luceria. One skirted the Adriatic, and though open and unobstructed, was long almost in proportion to its safety. The other led through the Caudine Forks, and was shorter, but this is the nature of the place; two deep defiles, narrow and wooded, are connected by an unbroken range of mountains on either hand; shut in between them lies a rather extensive plain, grassy and well-watered, with the road running through the middle of it; but before you come to it, you must enter the first defile, and afterwards either retrace the steps by which you made your way into the place, or else - should you go forward - pass out by another ravine, which is even narrower and more difficult. ${ }^{1}$
\end{abstract}

The well-known passage which introduces the episode of the battle and overwhelming defeat of the Roman army at the Caudine Forks has been the subject of various topographical studies. However, as N. Horsfall ironically underlined in his article "The Caudine Forks: Topography and Illusion", ${ }^{2}$ the Livian depiction of the battle does not match the actual topography. Horsfall thus assumed that Livy had no knowledge of geography to speak of, moreover, that the historian did not care that he should give a realistic representation of an Italian space. The place of the Caudine Forks does not belong to any set of remote territories; it is not far from Rome itself. Yet, “[Livy's] geography of the Second Samnit War is a known nadir. That the terrain lay between Rome and Campania did nothing to stir an accurate interest in Livy". ${ }^{3} \mathrm{~N}$. Horsfall's harsh judgement is not uncommon, but rather a part of the longstanding tradition of Roman historiographical studies.

Opposition of hypercriticism and high-degree fidelity has now given way to new criticism which focuses on the narratological work of ancient historians, ${ }^{4}$ following the shift of the "linguistic turn". ${ }^{5}$ Yet, and even though the latest archaeological discoveries contribute to rehabilitate the historians' reliability, the view of ancient his-

1 Translation by Foster 1926. In this article I use the Loeb editions, unless otherwise specified.

2 Horsfall 1982.

3 Horsfall 1982, 50.

4 Miles 1995; Jaeger 1997; Feldherr 1998; Mineo 2006; Levene 2010.

5 White 1973 and 1987; Wiseman 1979; Woodman 1988.

Ә OpenAccess. (C) 2021 Mario Baumann, Vasileios Liotsakis, publiziert von De Gruyter. 
torians' lack of geographical and topographical knowledge still prevails. When they do not lament on ancient historians' lack of accuracy, or their lack of knowledge and interest in geography, researchers often claim that ancient historiography omits referential information and leaves only rhetorical images of typical places in order to serve a defined purpose. N. Horsfall thus tried to demonstrate that the episode of the Caudine Forks is framed with topical elements which belong to many other depictions in narratives of conquest. These stories indeed unfold the tactical space of a confined location, made of narrow defiles, hostile vegetation and steep slopes that hide ambushes which make it difficult for the army to progress, and, for example, the two narrow wooden passes (saltus duo alti angusti silvosique) recall to N. Horsfall the stories of Alexander the Great. ${ }^{6}$ Three years later, in another paper about ancient geographical depictions' issues, he concluded:

Such geography appeals to a taste for the curious, the mythical, the strange and the picturesque. Such information is meant to entertain rather than to instruct; a matter for enjoyment, not study. No expectation existed in Augustan Rome that the geographical information contained in a work of literature should be precise. ${ }^{7}$

Such dichotomy between enjoyment and study is surprising, and N. Horsfall seems to postulate too quickly here. It would certainly be helpful, as he discusses the expectations (specifically, the absence of expectations) of the Roman audience, to understand which type of audience (or audiences) there was in the Augustan period. In fact, I believe that the confusions and inaccuracies which the researchers identify in historical descriptions often illustrate a horizon of expectations built by the texts, which refers to the horizon of expectations of the actual audience, albeit not completely identical with it. Indeed, as H.R. Jauss pointed out, the audience must follow the reading strategies implied by the textual structures. ${ }^{8}$ In this respect, should the "inaccuracy" and "errors" be regarded as the product of both the historiographical and ethnogeographical traditions ${ }^{9}$ and the concerns and knowledge of the audience? In this article I intend to re-read the ethnogeographical passages of ancient historical works in light of various criteria of reception, in order to suggest that the forms and content of such descriptions, as well as their accuracy, may be determined by the geographical and ethnological knowledge of the audience and by its various expectations. As a result, I will at first try to understand what the re-

6 See Curt. 3.4.11 for the depiction of the Cicilian Gates and 5.3.18-19 for the representation of the Persian Gates.

7 Horsfall 1985, 199.

8 Jauss 1982.

9 See Engels 2008, 541: "In the ancient Greco-Roman world the boundaries between genres of prose literature remained fluid and blurred. This was especially true of the twin disciplines of geography and history and of cultural-geographical and historical works of literature.” In this article, I will use the term "geography" in the contemporary sense to refer to the description of single areas, which was named "chorography" in Antiquity. See Jacob 1991, 128 commenting on Ptolemy 1.1.1. 
searchers mean when they blame the "inaccuracy" and "lack of precise information" of such texts. This will require a study of the elaboration of some descriptions in the historical works of the first century BCE, such as the excursus of Sallust on Africa, the depictions of the Hercynian Forest in the Bellum Gallicum, in addition to Livy's picture of an Etruscan Italy and his narrative of Celtic migration in the fifth century BCE. These historical works are written in the specific context of the achievement of Roman conquest and the establishment of a world inventory, ${ }^{10}$ with monumental or triumphal exhibitions of the conquered territories and peoples, while new and broader audiences emerge. This context will lead me, in a second part, to ask what the nature of the audience of such historiographical texts ${ }^{11}$ and its various degrees of access to ethnographical knowledge could be. Lastly, I hope to rethink the purposes of Latin historiography and to problematise the traditional opposition between utility and pleasure in this particular social and cultural context.

\section{1 "Inaccurate" depictions of the world: the ethno-geographical descriptions in Caesar, Sallust, and Livy}

It can be useful to come back to the texts and to study their content, specific terminology and sources, in order to understand how they differ from our conceptions of geographical descriptions.

\section{a Content and sources}

When they focus on ancient ethnogeographical passages, scholars often become very judgemental: for instance, when alluding to the Hercynian Forest's depiction, L.A. Constans suggests that the description is so filled with incredible information that Caesar certainly delegated his work to his - far less skilled and cultivated - secretaries:

So much is said [in book 5 of Bellum Gallicum] on the Hernicyan Forest's Fauna that we are reluctant to attribute it a mind like his [...]. Undoubtly Caesar wanted to offer to his lectorship information about remote lands where he first led the Roman army and appointed one of his secretaries to gather a few Greek geographers. ${ }^{12}$

10 Nicolet 1988.

11 Not forgetting that under the same label of "historical works" fall different texts, such as monograph, commentary and annalistic narrative, which are related to different purposes.

12 Constans 1926, XIV-XV. 
Even if he believed that Sallust had a full understanding of African ethnogeography, since he had been the governor of the Roman province there, R. Syme enumerated the "errors" made by Sallust in his digression and stated that the historian let his "Greek erudition and fancies betray their usual devastating effects". ${ }^{13}$ A similar assessment was given by P.G. Walsh on the $A b$ urbe condita:

Livy's personal deficiencies as historian are considerable - weakness of geography, ignorance of military matters, lack of acquaintance with politics. He is thus incapable of rigorous evaluation or original interpretation in these fields. The main conclusion stands out inescapably: Livy's value for Roman history varies according the source followed. ${ }^{14}$

However, to which "errors" or "approximations" do these scholars refer to? For example, the description of the Hercynian Forest in the sixth book of the Bellum Gallicum, which follows a comparison between Gallic and German peoples and a long excursus on Germany, begins with information on its size (6.25):

Huius Hercyniae silvae, quae supra demonstrata est, latitude nouem dierum iter expedito patet: non enim aliter finiri potest, neque mensuras itinerum nouerunt.

The breadth of this Hercynian forest, above mentioned, is as much as a nine days' journey for an unencumbered person; for in no other fashion can it be determined, nor have they means to measure journeys.

Yet, this information is not numerical, which can confuse a modern reader; it is rather measured according to the journey of a lightly equipped traveller. Caesar adds a commentary in which he explains that there are no other ways to measure it, but in fact, the use of the dative expedito is a commonplace of historical narratives; it makes mention of a footman. Such measurement system is part of the Herodotean tradition: when he referred to the width of spaces in the Histories (1.72.3; 1.104.1 and 2.32.2), Herodotus mentioned the five days that it took to be journeyed by a lightly equipped man: ${ }^{15}$

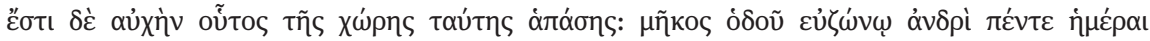

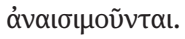

Here is the narrowest neck of all this land; the length of the journey across is five days, for a man going unburdened.

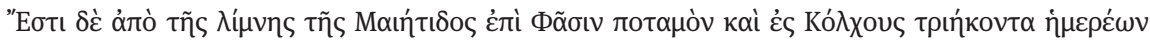

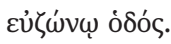

It is thirty days' journey for an unburdened man from the Maeetian lake to the river Phasis and the land of the Colchi.

13 Syme 1964, 152-153.

14 Walsh 1961, 273.

15 See Briscoe's comment on Liv. 38.59.6 (2008, 206). 


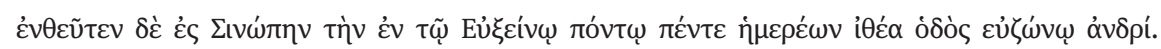

Whence it is a straight five days' journey for an unburdened man to Sinope on the Euxine. ${ }^{16}$

A second criterion could cause uncertainty for the modern reader: the location which follows the mention of the width of the Forest (Gal. 6.25):

Oritur ab Helvetiorum et Nemetum et Rauracorum finibus rectaque fluminis Danubi regione pertinent ad fines Dacorum et Anartium; hinc se flectit sinistrorsus diversis ab flumine regionibus multarumque gentium fines propter magnitudinem adtingit.

It begins in the borders of the Helvetii, the Nemetes, and the Rauraci, and, following the direct line of the river Danube, it extends to the borders of the Daci and the Anartes; thence it turns leftwards, through districts apart from the river, and by reason of its size touches the borders of many nations.

It only refers to the River Danube and German peoples, in sharp contrast to these of Strabo in the seventh book of his Geography (7.1.5), and of Pomponius Mela in the third book of his Chorography (3.25), both of whom use various natural elements, in order to help localisation:

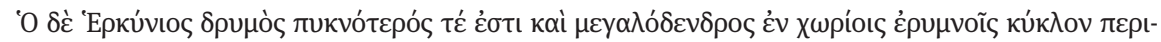

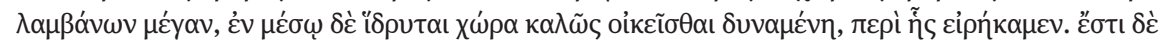

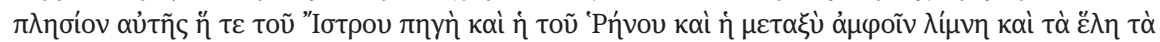

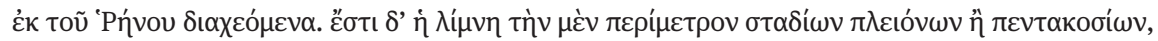

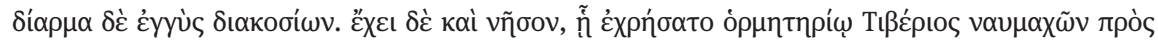

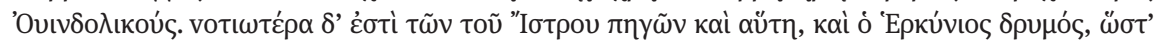

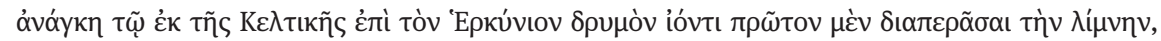

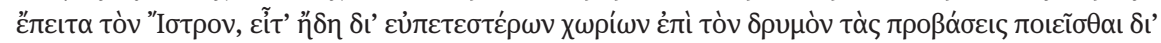

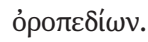

The Hercynian Forest is not only rather dense, but also has large trees, and comprises a large circuit within regions that are fortified by nature; in the centre of it, however, lies a country (of which I have already spoken) that is capable of affording an excellent livehood. And near it are the sources of both the Ister and the Rhenus, as also the lake between the two sources, and the marshes into which the Rhenus spreads. The perimeter of the lake is more than three hundred stadia, while the passage across it is nearly two hundred. There is also an island in it which Tiberius used as a base of operations in his naval battle with the Vindelici. This lake is south of the sources of the Ister, as is also the Hercynian Forest, so that necessarily, in going from Celtica to the Hercynian Forest, one first crosses the lake and then the Ister, and from there on advances through more passable regions - plateaus - to the forest. ${ }^{17}$

Paludium Suesia, Metia et Melsyagum maximae, silvarum Hercynia et aliquot sunt, quae nomen habent, sed illa dierum sexaginta iter occupans, ut maior aliis ita notior.

16 Translated by Godley 1920.

17 Translated by Jones 1924. 
Of the swamps, the Suesia, the Metia, and the Melsyagum are the biggest. Of the forests, the Hercynian and some others that have names do exist, but because it covers sixty days' march, the Hercynian Forest is as much better known as it is bigger than the others. ${ }^{18}$

Moreover, the texts do not provide systematic knowledge but carefully selected items. In each one, common themes of historiography are involved: first, the theme of origines gentium (peoples' origins), ${ }^{19}$ with the mention of migrations because of poverty and overcrowding (Jug. 18.11; 19.1; Liv. 5.33-34). Second, the evocation of settlements of groups who followed Hercules during his wandering all over the Mediterranean world, in Sallust (Jug. 18.3), is echoed by Livy's allusion to the legend of Hercules crossing the Alps (5.34.6). Third, the theme of the onset of decadence as a result of the onset of foreign influences and luxury (Liv. 5.33.11): ${ }^{20}$

Alpinis quoque ea gentibus haud dubie origo est, maxime Raetis, quos loca ipsa efferarunt ne quid ex antique praetor sonum linguae, nec cum incorruptum, retinerent.

The Alpine tribes have also, no doubt, the same origin, especially the Raetians; who have been rendered so savage by the very nature of the country as to retain nothing of their ancient character save the sound of their speech, and even that is corrupted.

On the contrary, peoples who remain in a rough territory are thought to keep their physical fitness in order to endure strenuous exertions (Jug. 17.5-6). Similarly, the Hercynian Forest, as an unreachable edge of the known world, stands for the virtues of the Germans, who were opposed by Caesar to the decadent Gauls in the previous paragraph (Gal. 6.25):

Neque quisquam est huius Germaniae, qui se aut adisse ad initium eius silvae dicat, cum dierum iter LX processerit, aut quo ex loco oriatur acceperit.

There is no man in Germany we know who can say that he has reached the edge of that forest, thought he may have gone forward a sixty days' journey, or who has learnt in what place it begins.

\section{b Specific terminology}

These geographical depictions are characterized by a specific terminology: oriuntur, pertinet ad, se flectit and adtingit are dynamic verbs, in that they convey the idea of movement or direction. They were often used in Latin geographical texts, as Th.

18 Translation by Romer 1998.

19 Bickerman 1952. It has already become a common theme in rhetoric; a century later Seneca used it in his Consolatio ad Helviam matrem, 7.2-4.

20 This theme goes back to Pl. Lg. 4.704b-705b and Arist. Pol. 7.1327. It is a commonplace in Rome: see Cic. Rep. 2.3.5 and the speech of Camillus in Liv. 5.54. 
Becker already noted. ${ }^{21}$ Nevertheless, apart from this dynamic perspective, the description seems to follow a hodological perspective. Directions and orientations are numerous but rather inaccurate, since they only shape an imprecise layout: $a b$ ... recta ... ad ... hinc ... sinistrorsus. Similarly vague is the terminology: the word fines refers to unclearly defined territories, ${ }^{22}$ and regiones or gentes are said simply to be plentiful and various (multae, diversae). In his famous depiction of Africa in his monograph on the Jugurthine War, Sallust also uses geographical terms for orientation - such as $a b$ occidente and $a b$ ortu solis -, yet also remains vague and uses generical terms such as magna pars or pleraque. Nor does he give accurate localisations. Indeed, the narrative goes from one place to another, in the same hodological line. The same structure can be found in Livy's depiction of Italy as well, in the fifth book of the $A b$ urbe condita, before the Gallic invasion. This passage is placed into a flashback, which narrates the first invasion of Italy, in the time of Tarquin, when northern Italy was mostly ruled by the Etruscan cities. Dynamic terms are also used, such as cingitur and vergere. The depiction does not choose the terminology of geographical ancient tradition - those of Eratosthenes, Hipparchus or Polybius - in which the audience is given geometrical descriptions where Italy stands for a triangle whose top is the headland of Cocynthos, in Bruttium, and whose base consists of the Po Valley and the Alps (Plb. 2.14.4):

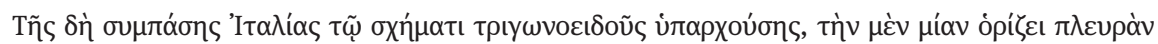

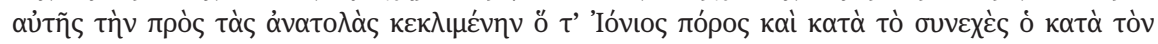

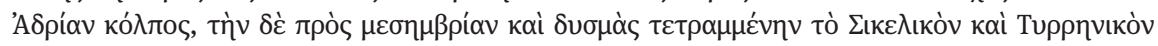

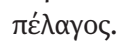

Italy as a whole has the shape of a triangle of which one or eastern side is bounded by the Ionian Strait and then continuously by the Adriatic Gulf, the next side, that turned to the south and west, by the Sicilian and Tyrrhenian Seas. ${ }^{23}$

\section{c Sources}

Scholars also criticized these historians' use of sources and dismiss the seriousness of the geographical information that they gave in their texts. Yet, ancient historians did not usually refer to their own experience, nor to a knowledge provided by the experience of travelling. They built their personae of a narrator/historian who possesses a serious knowledge, but a literary one: Sallust thus links the information he gave to his audience to a geographical work that must have been authoritative in the geography of Africa, namely the Punic books of King Hiempsal. Yet, surprisingly, he is very vague when he alludes to his other sources, with the term plerique.

21 Becker 1900.

22 See Trousset 1993.

23 Translation by Patton 1922, revised by Walbank and Habicht 2010. 
The same inaccuracy can be found when Caesar mentions Eratosthenes and "Greek authors" (quidam Graeci): he sets himself in both the tradition of the great scholar of the third century BCE who was still the main reference for geographical knowledge in the first century $\mathrm{BCE},{ }^{24}$ and of various unnamed geographers. Therefore, Caesar and Sallust did not mention their own experience of a space they knew perfectly already, as the former conquered it and the latter ruled it as a governor, and only offered bookish information. Livy may have also used a literary tradition: in truth, R.M. Ogilvie suggested that Livy's passage on northern Italy was also written in the Tuscana Historia and refers to the tradition of Etruscology. ${ }^{25}$ Indeed, A. Feldherr ${ }^{26}$ has recently noted that Latin historians gave up autopsy and investigation, which were major precepts in Greek historiography. He demonstrated that, in Roman historiography, the look is no longer a direct look on actual events. The perspective rather belonged to the audience, which acted as both the receptacle and the actor of the spectacle of great deeds.

To conclude this section, ethno-geographical depictions in these historiographical narratives of course do not satisfy the contemporary criteria of geographical depictions, as they had to meet very different expectations: those of an audience which was used to ancient historiographical tradition, to its specific vocabulary, themes and ways to refer to its sources. This audience of historiography was not interested in "scientific geography"27, but rather in a knowledge of the territories which happened to belong to the new Roman Empire. In order to reach a better understanding of such audience's expectations, we will now investigate the model reader ${ }^{28}$ who is mirrored by ancient historiographical texts.

\section{Model reader and ethno-geographical knowledge}

\section{a A broader audience}

In some historical works we find dedications which indicate that the works were devoted to characters who were mostly members of the political elite, such as the dedication of Hirtius, Caesar's lieutenant, to Lucius Cornelius Balbus (Gal. 8.1):

24 See Aujac 2001. In a letter to Atticus, Cicero refers to Eratosthenes as an exemplary model: Cic. Att. 2.6.2.

25 Ogilvie 1965, 703; Suet. Cl. 42.2 tells us that Claudius, who was also Livy's pupil, was the author of an Etruscan history. See Briquel 1988.

26 Feldherr 2009.

27 Clarke 1999.

28 We believe that these historical works of the end of the Roman Republic presented a single model of reader, in contrast with those of the Flavian Era, such as Arrian's Anabasis, which shows the concern of readerly diversity. On Arrian, see V. Liotsakis in this volume. 
Coactus assiduis tuis vocibus, Balbe, cum cotidiana mea recusatio non difficultatis excusationem sed inertiae videretur deprecationem habere, rem difficillimam suscepi.

By your continual reproaches, Balbus, which seemed to regard my daily refusal not as a plea caused by difficulty, but as an evasion due to indolence. ${ }^{29}$

Through this form of dedication, people who oversaw political life could thus be informed of foreign affairs or were given lessons from history (as magistra vitae). In the first century BCE, however, Roman historiography experienced an important growth that is shown by the increasing number of historical works. ${ }^{30}$ The historians' works therefore seem to have reached a larger audience. As $\mathrm{Cl}$. Moatti ${ }^{31}$ underlined, after the civil wars, Roman people experimented a genuine need for history, as they tried to strengthen the foundations of their knowledge of the past. A shift then occurred in the intellectual world. Historiography was no longer put forward as the natural prolongation of the political activities of the Roman elite but as a source of fame for historians who did not necessarily belong to the political field. ${ }^{32}$ This is evidenced by a passage of Pliny the Elder, where Livy is said to have praised his own glory in the preface of a book which is now lost (Nat. pr. 16):

Equidem [...] profiteor mirari me T. Livium, auctorem celeberrimum, in historiarum suarum quas repetit ab origine urbis, quodam volumine sic orsum: iam sibi satis gloriae quaesitum, et potuisse se desidere, ni animus inquies pasceretur opere. profecto enim populi gentium victoris et Romani nominis gloriae, non suae, conposuisse illa decuit.

For my own part [...] I declare that I admire the famous writer Livy when he begins one volume of his History of Rome from the Foundation of the City with the words 'I have already achieved enough of fame, and I might have retired to leisure, did not my restless mind find its sustenance in work'. For assuredly he ought to have composed his history for the glory of the world-conquering nation and of the Roman name, not for his own. ${ }^{33}$

The historian, orator and politician made way for the professional rhetor; the listener of a recitatio did not inevitably belong to the familiar circle of the author ${ }^{34}$ and the work then circulated beyond the network of friends or acquaintances. ${ }^{35}$

Furthermore, the importance of orality in Roman culture ${ }^{36}$ enabled the oral circulation through the city of entire books or, rather, of selected excerpts. As speaking

29 Translation by Edwards 1917.

30 in tanta scriptorum turba, said Livy in the preface of his historical opus (pr. 3).

31 Moatti 1997.

32 See Ledentu 2004, "Conclusion".

33 Translation by Rackham 1938.

34 See Sen. Con. 3 pr. 12, and Videau 2000; de Franchis 2012.

35 See Valette-Cagnac 1997, 111-167.

36 See Harris 1989. 
was a more important vector than writing, ${ }^{37}$ the low literacy level in Roman society did not prevent people from accessing such texts: ${ }^{38}$ while Pollio Asinius, as Seneca the Elder showed it in his Controuersiae, read his books in front of a selected audience, ${ }^{39}$ Livy was indeed represented by Pliny the Younger as giving a public hearing, where an inhabitant of the remote Gades, from the border of the western world, came to see him and went back right away (Ep. 2.3.8):

Numquamne legisti, Gaditanum quendam Titi Livi nomine gloriaque commotum ad visendum eum ab ultimo terrarum orbe venisse, statimque ut viderat abisse? $\dot{\alpha} \varphi \iota \lambda$ ó $\alpha \lambda$ ov inlitteratum iners ac paene etiam turpe est, non putare tanti cognitionem qua nulla est iucundior, nulla pulchrior, nulla denique humanior.

Have you never heard the story of the Spaniard from Gades? He was so stirred by the famous name of Livy, that he came from his far corner of the earth to have one look at him and then went back again. Only a boorish ignorance and a degree of apathy which is really rather shocking could prevent you from thinking it worth an effort to gain an experience which will prove so enjoyable, civilized, and rewarding. ${ }^{40}$

Moreover, an excerpt of Cicero also testifies to the spread of historiography beyond the small circle of Roman political elite: in fact, it even seems that lower sections of the population had current access to historical narratives (Fin. 5.51-52): ${ }^{41}$

\begin{abstract}
Ipsi enim quaeramus a nobis [...] quid historia delectet, quam solemus persequi usque ad extremum, praetermissa repetimus, inchoata persequimur. nec vero sum nescius esse utilitatem in historia, non modo voluptatem. quid, cum fictas fabulas, e quibus utilitas nulla elici potest cum voluptate legimus? quid, cum volumus nomina eorum qui quid gesserint nota nobis esse, parentes, patriam, multa praeterea minime necessaria? quid quod homines infima fortuna, nulla spe rerum gerendarum, opifices denique delectantur historia? maxime eos videre possumus res gestas audire et legere velle qui a spe gerendi absunt confecti senectute. quocirca intellegi necesse est in ipsis rebus quae discuntur et cognoscuntur invitamenta inesse quibus ad discendum cognoscendumque moveamur.
\end{abstract}

Let us ask ourselves the question [...] why we derive pleasure from history, which we are so fond of following up, to the remotest detail, turning back to parts we have omitted, and pushing on to the end when we have once begun. Not that I am unaware that history is useful as well as entertaining. But what of our reading fiction, from which no utility can be extracted? What of our ea-

37 See Harris 1989, 226: "The heavy reliance for the Roman upper class on readers is familiar, and even for them it is clear that listening, instead of reading for oneself, always seemed natural." 38 According to M. Corbier, it did not prevent them from accessing public communication, as we can speak of a "poor literacy" of Roman society, i.e. some ability to read capital letters: Corbier 2006. 39 Pollio Asinius numquam admissa multitudine declamauit, nec illi ambitio in studiis defuit; primus enim omnium Romanorum advocatis hominibus scripta sua recitavit (Sen. Con. 4 pr. 2), "Asinius Pollio never let a crowd in when he declaimed; but he was not without scholarly ambition - indeed he was the first of all of the Romans to recite what he had written before an invited audience" (translation by Winterbottom 1924).

40 Translation by Radice 1919.

41 For a better understanding of this quotation considering the reading of Livy's work, see D. Pausch in this volume. 
gerness to learn the names of people who have done something notable, their parentage, birthplace, and many quite unimportant details beside? What of the delight that is taken in history by men of the humblest station, who have no expectation of participating in public life, even mere artisans? Also we may notice that the persons most eager to hear and read of public affairs are those who are debarred by the infirmities of age from any prospect of taking part in them. Hence we are forced to infer that the objects of study and knowledge contain in themselves the allurements that entice us to study and to learning. ${ }^{42}$

T.P. Wiseman suggested in his article "Practice and Theory in Roman Historiography" that in Rome historical texts were often read in front of large audiences, mostly in public spaces such as fora or baths:

Public recitation, mass audiences, but no purpose-built auditoria - so where did the literary men of the late Republic perform? Horace gives us the answer: in the Forum, in the baths, and (after 55 BCE) in the theatre. The terraced steps of the Comitium, or the gradus Aurelii, would be an ideal spot on holidays when there was no public business in the Forum; the theatre, on the other hand, would be available on working days but not during ludi scaenici. The baths could be used any time, as could the scholae and exedrae of the public colonna. ${ }^{43}$

Literature - especially historical works - could thus be broadly received. One can wonder if this broader audience was extended to the provinces of the Roman Empire. In fact, given the spread of the use of Latin at the expense of indigenous languages in particular, in the western part of the Roman Empire -, we can assume that in the first century BCE at least the provincial elite was able to understand Latin readings. ${ }^{44}$

Now, reading historical narratives aloud in public or private spaces may have conveyed a particular reception. ${ }^{45}$ Even if this can only be speculated, as it is not possible to reconstitute a reading performance in Rome, it can at least be suggested that these practices, which took place in various settings, must have brought to Rome and all over the Empire images and sounds from other territories which were part of the imperium Romanum. I believe that they offered an overlap, or rather a conflation of spaces within the exact place of reception.

42 Translation by Rackham 1914.

43 See Wiseman 1981, 385. In addition to the excerpt of Cicero's De Finibus, he notably uses quotations of Hor. Sat. 1.4.73-76 and Ep. 1.19.41.

44 Harris 1989, 175-190.

45 As M. Corbier warns us, we must not expeditiously identify the audience of oral readings with popular ones, as oratory form clearly corresponds to elite culture. In fact, orality results from a constant dialogue between elite and mass: Corbier 2006, 73-75. 


\section{b Various kinds of ethno-geographical knowledge, belonging to different audiences}

How can the ethno-geographical knowledge of such a broader audience be analysed? The letters of Cicero present him as an intellectual who actively compiled a network to purchase scholarly books, or who complained about the difficulties of gathering material and writing according to geographical criteria (Att. 2.6.2):

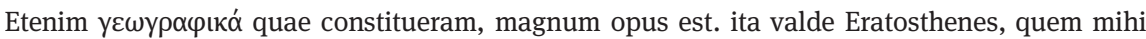
proposueram, a Serapione et ab Hipparcho reprehenditur. quid censes, si Tyrannio accesserit? et hercule sunt res difficiles ad explicandum et ó $\mu$ quam videbantur.

The geographical work I had planned is a big undertaking. Eratosthenes, whom I had taken as my authority, is severely criticized by Serapion and Hipparchus; and, if I take Tyrannio's views too, there is no telling what the result will be. Besides the subject is confoundedly hard to explain and monotonous, nor does it give one as many opportunities for flowers of fancy as I imagined. ${ }^{46}$

Yet, geographical written knowledge, in all its complexity, ${ }^{47}$ is not the prerogative of the individual scholars. In the first century BCE, ethno-geographical information could come from multiple sources, such as reports from travellers, traders, generals or governors: the intensification of trade was of course the main source of geographical knowledge. ${ }^{48}$ It was also compounded by the numerous military expeditions all around the Mediterranean Sea, as Cicero reminds us in his political oratory (Prov. 13.33):

et, quas regiones quasque gentes nullae nobis antea litterae, nulla vox, nulla fama notas fecerat, has noster imperator nosterque exercitus et populi Romani arma peragrarunt.

Other these regions and races, which no writings, no spoken word, no report had before made known to us, over them have our general, our soldiers, and the arms of the Roman People made their way. ${ }^{49}$

$\mathrm{Cl}$. Moatti has underlined how much these new forms of knowledge were the result of a deliberate work of compiling and diffusing ethno-geographical expertise, which was led by the Romans during their conquests. She also reminded us that Polybius mostly drew his information from Laelius, who followed Scipio to Spain and Africa during the Second Punic War, from Cato, who was sent to Spain in 195 BCE, or from

46 Translation by Winstedt 1912.

47 Arnaud 2007.

48 Think of the epitaph of this first century BCE merchant in Brindisi: Si non molestum est, hospes, consiste et lege. navibus velivolis magnum mare saepe cucurri, accessi terras complures, "If it is not unpleasant, host, stay and read. I have often travelled in the open sea in sailing ships, I went to many lands" (Porte 1993, 18).

49 Translation by Gardner 1958. 
Ti. Sempronius Gracchus, who was charged with many diplomatic missions in Greece and Asia. ${ }^{50}$ The Roman people of the first century BCE were fully aware of the new developments in knowledge from such campaigns and traveling, as it can be seen in Varro's treatise on agriculture, in which a discussion takes place between members of the political elite on physical geography and ethnography (R. 1.7.8 and 2.10.8-9):

In Gallia transalpina intus, ad Rhenum cum exercitum ducerem, aliquot regiones accessi, ubi nec vitis nec olea nec poma nascerentur, ubi agros stercorarent candida fossicia creta, ubi salem nec fossicium nec maritimum haberent, sed ex quibusdam lignis combustis carbonibus salsis pro eo uterentur.

When I was in command of the army in the interior of Transalpine Gaul near the Rhine, I visited a number of spots where neither vines nor olives nor fruit trees grew; where they fertilized the land with a white chalk which they dug: where there had no salt, either mineral or marine, but instead of it used salty coals obtained by burning certain kinds of wood.

Simul aspicit ad me et, 'Ut te audii dicere, inquit, cum in Liburniam venisses, te vidisse matres familias eorum adferre ligna et simul pueros, quos alerent, alias singulos, alias binos.'

At the same time, turning to me, he said: 'As I have heard you say that you, when you were in Liburnia, saw mothers carrying logs and children at the breast at the same time, sometimes one, sometimes two. ${ }^{51}$

Even if there is no point in seeking a political process of systematic inventory of the world in this period, ${ }^{52}$ it can still be said that ethno-geographical forms of knowledge reached a broader and more varied public than before. This public included, beyond the circle of navigators, merchants, soldiers, and most of the population. In rhetorical schools, young people learnt common characteristics and names of foreign places: for instance, one instruction from the Rhetoric for Herennius asked students to praise the comparative advantages of different spaces of the new Roman world (3.2):

Ut si Hannibal consultet, quom ex Italia Kartaginem arcessatur, an in Italia remaneat, an domum redeat, an in Aegyptum profectus occupet Alexandriam.

If Hannibal, when recalled to Carthage from Italy, should deliberate whether to remain in Italy, or return home, or invade Egypt and seize Alexandria.. ${ }^{53}$

Furthermore, travel narratives, such as periegeseis or itineraria, and pictures, if not maps, ${ }^{54}$ made available geographical knowledge in the places of daily life. In ch. 1.2.1-3 of Res Rusticae, Varro's father-in-law and his friend, who is a philosopher,

50 Moatti 1997, 65.

51 Translation by Hooper 1934.

52 The inventory process must be situated within the Flavian Era. See Rouveret 1987.

53 Translation by Caplan 1954.

54 See Chevallier 1986 and Sherk 1974. These maps must have been distorted, as the method of projection that was used was inadequate. See Rambaud 1987. 
could contemplate a map of Italy which is hung in the temple of Tellus. They tried to interpret it with their knowledge, which is characteristic of their social status:

Sementivis feriis in aedem Telluris veneram [...]. offendi ibi C. Fundanium, socerum meum, et C. Agrium equitem R. Socraticum et P. Agrasium publicanum spectantes in pariete pictam Italiam [...]. cum consedissemus, Agrasius, 'Vos, qui multas perambulastis terras, ecquam cultiorem Italia vidistis?' inquit. 'Ego vero, Agrius, nullam arbitror esse quae tam tota sit culta. primum cum orbis terrae divisus sit in duas partes ab Eratosthene maxume secundum naturam [...].'

On the festival of the Sementivae I had gone to the temple of Tellus [...]. I found there Gaius Fundanius, my father-in-law, Gaius Agrius, a Roman knight of the Socratic school, and Publius Agrasius, the tax-farmer, examining a map of Italy painted on the wall [...]. When we had taken our seats Agrasius opened the conversation: 'You have all travelled through many lands; have you seen any land more fully cultivated than Italy?' 'For my part', replied Agrius, 'I think there is none which is so wholly under cultivation. Consider first: Eratosthenes, following a most natural division, has divided the earth in two parts [...]. ${ }^{35}$

However, any passerby could have gone past the temple and attempted to compare Italy with other territories. Texts from Livy or Pliny the Elder mention maps or pictures which decorated temples or monuments:

Liv. 41.28.8

Eodem anno tabula in aede Matris Matutae cum indice hoc posita est [...]. Sardiniae insulae forma erat, atque in ea simulacra pugnarum picta.

In the same year a tablet was set up in the temple of Mater Matuta with this inscription [...]. It had the form of the island of Sardinia, and on it representations of battles were painted. ${ }^{56}$

Plin. Nat. 5.5.36-37

Et hoc mirum, supra dicta oppida ab eo capta auctores nostros prodidisse, ipsum in triumpho praetor Cidamum et Garamam omnium aliarum gentium urbiumque nomina ac simulacra duxisse, quae iere hoc ordine: Tabudium oppidum, Niteris natio, Milgis Gemella oppidum, Bubeium, natio vel oppidum, Enipi natio, Thuben oppidum, mons nomine Niger, Nitibrum, Rapsa oppida [...] mons Gyri, in quo gemmas nasci titulus praecessit.

There is also this remarkable circumstance, that our writers have handed down the names of the towns mentioned above as having been taken by him, and have stated that in his own triumphal procession beside Cydamum and Garama were carried the names and images of all the other peoples and cities, which went in this order: the town of Tibesti, the Niteris tribe, the town of Milgis Gemella, the tribe or town of Febabo, the tribe of the Enipi, the town of Thuben, the mountain known as the Black Mountain, the towns called Nitibrum and Rapsa [...] and Mount Goriano, its effigy preceded by an inscription that it was a place where precious stones were produced..$^{57}$

55 Translation by Hooper 1934.

56 Translation by Sage and Schlesinger 1938.

57 Translation by Rackham 1942. 
The dissemination of knowledge was therefore not specific to writing; it was also conveyed by orality, but above all by spectacles producing geographical information. Indeed, P. Zanker ${ }^{58}$ and K. Galinsky ${ }^{59}$ have insisted on the spectacular dimension of Roman society and on the use of images by Republican elites and then by the new Augustan power. ${ }^{60}$ Both Republican and Augustan holders of power built their authority through public ceremonies such as collective meetings, justice courts, theatre, funeral or triumphal processions. The latter included the temporary exhibition of panels with geographical names or pictures, which were then permanently shown in temples, houses or libraries. ${ }^{61}$ Augustus even built a monument to give a verbal map of the conquered world: while J. Scheid ${ }^{62}$ has shown us that the Res Gestae may have been written for the elite who were able to decrypt the inscription or to ask for an explanation, the monument was also destined for the whole population of Rome, and moreover, for the citizens of the Empire, as it was duplicated in Ancyra, Antioch and Apollonia. Furthermore, the so-called map of Agrippa may have been a more explicit way to popularize geographical information within the Roman population. At the same time, while the porticus Vipsania was decorated by either a map or only by a list of territories, as P. Arnaud notes, ${ }^{63}$ Augustus' lieutenant, Agrippa, moved geography down within the City and made it visible to everyone. Roman space was therefore saturated with representations of foreign territories. They may have had a more expressive function than a referential one, and the spectacular aim probably prevailed over the didactic one, ${ }^{64}$ as they were designed to be seen from a distance. Yet, all these images provided pictures and sounds of the unknown and extended world: many sources testify to the universal accessibility of this geographical knowledge.

Even more, it seems possible that groups of citizens could have reproduced maps of countries on the ground, as the Athenian people are reported to have done so, according to Plutarch's account of the debate on an Athenian expedition to Sicily (Nic. 12.1):

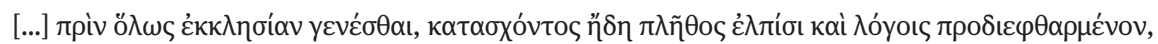

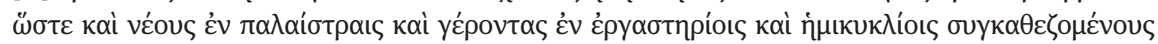

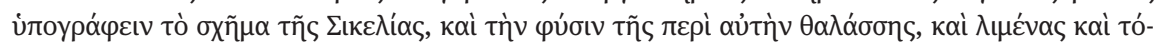

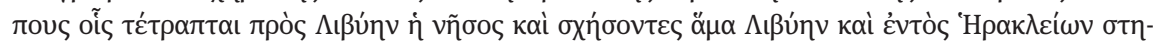
$\lambda \tilde{\omega} \nu \theta \alpha \dot{\lambda} \lambda \alpha \sigma \sigma \alpha \nu$.

\footnotetext{
58 Zanker 1987, 1991 and 2000.

59 Galinsky 1996.

60 However, these images are not directly imposed by the power but implemented by elites and citizens all around the empire. See Zanker 1991, 193-220 and 2000, 211-245.

61 See Str. 5.3.8; Plin. Nat. 36.29; 38; 50.113-115; Vitr. 6.5; Cic. Ver. 4.6.

62 Scheid 2007, XXXIV-XXXVI.

63 Arnaud 2009.

64 See Mery 2012, 153.
} 
Before the assembly had met at all, Alcibiades had already corrupted the multitude and got them into his power by means of his sanguine promises, so that the youth in their trainingschools and the old men in their work-shops and lounging-places would sit in clusters drawing maps of Sicily, charts of the sea about it, and plans of the harbours and districts of the island which look towards Libya. For they did not regard Sicily itself as the prize of the war, but rather as a mere base of operations, purposing therefrom to wage a contest with the Carthaginians and get possession of both Libya and of all the sea this side the Pillars of Heracles. ${ }^{65}$

This narration illustrates an increase of geographical knowledge. Similarly, an elegy of Propertius shows this broader access to geographical expertise. It portrays a woman who uses a sort of map and geographical information to mentally follow the journey of her husband Lycotas who had gone to war to the eastern edges of the world (Prop. 4.3.7-10 and 33-40):

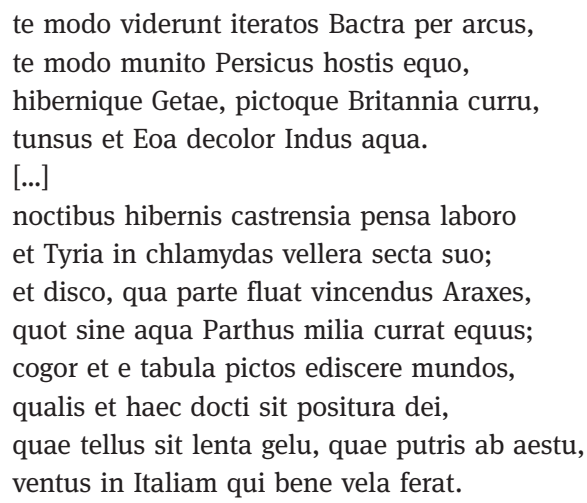

\begin{abstract}
Now you were seen by Bactra amid drawn bows, now by the Persian foe mounted on his mailed charger, by the northern Getans, by Britain with its painted chariots and the swarthy Indians pounded by orient waves [...]. I learn where flows the Araxes that you are to conquer, how many miles a Parthian horse can cover without water; and I am constrained to find out from a map the countries painted on it and the manner of this arrangement by the wise creator, what lands are sluggish with frost, what crumbling with heat, what wind will bring sails safely back to Italy. ${ }^{66}$
\end{abstract}

The characteristic inversion of Latin elegy, where the poet becomes a soldier of love, is here interpreted in a literal way, as the puella neglects her pensum to find out more about remote territories. Yet, it also evidences the accessibility of such information and the use of cartographic tools by ordinary citizens. The latter were therefore able to access actual geographical knowledge, far from a single rumour - the vulgata opinio - which was mostly based on fama and frequently mocked by the historians themselves. As one example of this, in the fortieth book of the Ab urbe condita, and when, because he relied on a widespread opinion, Philip of Macedonia decided to 
climb the Haemus mountain, Livy explains that he did so because he believed that he would be able to see the road that could lead his army to Italy (Liv. 40.21.2-22.5):

Cupido eum ceperat in verticem Haemi montis ascendendi, quia volgatae opinioni crediderat Ponticum simul et Hadriaticum mare et Histrum amnem et Alpes conspici posse. [...] nihil vulgatae opinioni degressi inde detraxerunt, magis credo, ne vanitas itineris ludibrio esset, quam quod diversa inter se maria montesque et amnes ex uno loco conspici potuerint.

The desire had seized him of climbing to the top of the Haemus mountains, because he had accepted the common opinion that from there could be seen all at once the Pontic and Adriatic seas, the Hister river and the Alps. [...] When they descended they did nothing to detract from the common opinion, rather, I suppose, to prevent the futility of the journey from becoming a subject of jest than because the different seas and mountains and rivers could be seen from one place. ${ }^{67}$

As a result of this evidence, I would suggest that these historical texts of the first century BCE were intended for a particular audience, who was no longer the political elite, but who consisted of a broader part of the Roman population - and undoubtedly of the provincial elite. The latter now had access to an ethno-geographical knowledge which was mostly conveyed by education and by the images located all over the cities. I believe that the spatial depictions in historical works were destined for the same audience. Historians seemed thus to try to shape their descriptions in order to fit to the expectations of such audience. Can these conclusions help us to rethink the well-known purposes of ancient historiography, i.e. pleasure and utility?

\section{Considering the audience: rethinking the purposes of Latin historiography}

\section{a Pleasure and utility as Latin historiography's purposes}

Even if each author may not have meant the same thing when he spoke about pleasure and utility, all the ancient historical works seem to proclaim them as their main purposes. Dionysius of Halicarnassus observed this, when he evoked Theopompus (Pomp. 6):

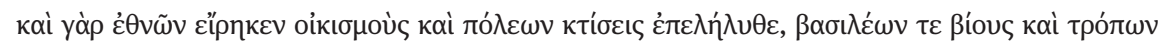

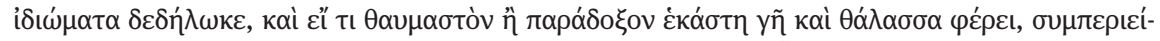

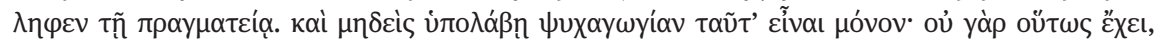

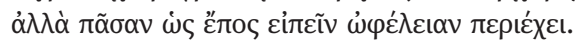

He has related the settlements of tribes, described the foundation of cities, portrayed the lives of kings and peculiarities of custom, and has included in his work everything remarkable or extra-

67 Translation by Sage and Schlesinger 1938. 
ordinary contained in every single land and sea. And nobody should suppose that this is purely for our entertainment: this is not the case, but the material contained in it is virtually for practical benefit. ${ }^{68}$

In this chapter, Theopompus is presented by Dionysius as a model for historians, as he reported to his audience the key information about the world. It can be supposed that Dionysius considered that he did so with clarity and order, as he opposed him to Thucydides, whom he vigorously condemned for his obscurity and his confusion (Pomp. 3):

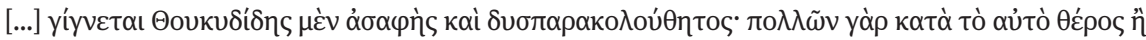

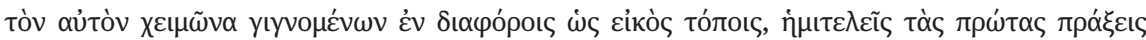

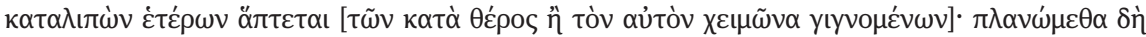

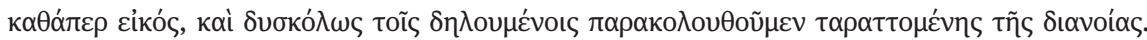

The result is that Thucydides is obscure and hard to follow, for since naturally many events occur in different places in the course of the same summer and winter, he leaves his account of earlier events half-finished and embarks upon others. Naturally we are bemused and feel annoyance as we try to follow the events he is describing because our minds are confused. ${ }^{69}$

As far as Dionysius is concerned, Thucydides does not seem to be a pleasant reading - except for the precise description of Sicily -, nor is he useful enough, as he is accused of losing his reader and of rejecting an ordered and organised textual structure. I believe that such a misunderstanding of Thucydides by the reader Dionysius stands for the purposes that, from Hecataeus of Miletus and Herodotus to the Roman tradition, the ancients expected from historiography in the first century BCE: they waited for the same ordered setting, with the same terminology and expectations, as R.F. Thomas summed it up in the introduction of his book on ethnography in Roman poetry:

1) Physical geography of the area

2) Climate

3) Agricultural produce, mineral resources, etc

4) Origins and features of the inhabitants

5) Political, social and military organisation

The works of Caesar and Sallust stand as clear evidence that the Greek ethnographical tradition has, before the Augustan period, passed into the mainstream of Roman literature. The same form was adopted, and an equivalent diction, to be equally formulaic, came into being. [...] Together with the shape, the position of the land is invariably described with reference to the points of the compass [...]. And lastly, further definition is provided by mention of major physical features, notably coastlines, seas, rivers and mountain ranges. ${ }^{70}$

68 Translation by Usher 1935. See also Plb. 15.36 .3 and Walbank 2002, 231; D.S. 1.3.5 and Sacks 1990. 69 Translation by Usher 1935.

70 Thomas 1982, 3. 


\section{b The need for clear geographical information on a new world: accuracy and enargeia}

This audience did not expect to be surprised by new information or literary forms. Rather, each author had to make his depictions easily accessible; consequently, he carefully shaped his narrative and inserted explicative comments, in order to provide a better understanding of historical action: so much is said by Cicero in De oratore 2.63: rerum ratio temporum desiderat, regionum descriptionem ("the nature of the subject needs chronological arrangement and geographical representation"71). Caesar's depiction of the Hercynian Forest thus seems to be used as a narrative delay before introducing a more important passage. The historian indeed quickly skips the spatial description and moves on to the ekphrasis of different marvellous animals of the forest. These depictions of the fauna of the Hercynian Forest seem to represent the climax of the passage, as if the historian's purpose was to amaze and entertain his readership after a quite long ethnographical comparison. Similarly, in his digression on Africa, Sallust looks as if he cares about his audience's attention, as he tells them that he will not offer a long geographical discussion but only a few selected items (see the adjectives pauci, the superlative paucissimi, and the verb attingere). In fact, this statement is a lie, considering the actual length of the excursus, but this is not relevant: these introductive words fulfil their function of directing and easing the audience, in a conversational tone. The use of adverbs of time such as deinde ... post ... dein underlines this same desire to facilitate the reading.

Surprisingly, whereas the Caesarean and Livian texts narrate a conquest and describe the progress of Roman armies, the standard was not necessarily the pace of a soldier but, rather, that of a traveller who is "lightly equipped". This means that these spaces should not be read as strategical or tactical ${ }^{72}$ where armies could unfold, but as spaces to picture.

Gone are the days when space was centred on a city. Now that Rome has become an Empire, Roman historians envisaged it by identifying urbs and orbis, the City and the world. ${ }^{73}$ As a result, they wrote spatial depictions according to their view of this new world. K. Clarke demonstrated that Strabo, whose audience is the same as Caesar's, no longer used traditional models of periplus or scientific geography but rewrote the world by transforming the use of linear concepts of space in conjunction with a different spatial model in which each individual place leads right up to Rome:

71 Translation by Sutton 1942.

72 According to the terminology established by Rambaud 1987.

73 Ov. Fast. 4.255-256; on this enlargement of the Roman domination to the world, see Nicolet 1988. Still, historians of the Republican or Augustan times let the perspective centered on Rome, while historians of the Imperial times, such as Tacitus, present Rome as a foreign space in which perspectives became divergent. See Ch.G. Leidl in this volume. 
By presenting a picture of the world as it was now, as well as its transformations into that state, Strabo could claim to be educating the ruling Romans on the nature of their subjects and potential enemies, providing an account of the lands and peoples which were of interest to the Roman ruling elite. ${ }^{74}$

Caesar thus wanted to depict the new world shaped by his conquests in the east; accordingly, he created in the sixth book a moment of narrative pause before putting forth the marvellous depiction of the fauna. The forest, whose width is unknown, appears as a typical border area, where no one can venture: non enim aliter finiri potest. Livy took up the same feature in his evocation of the impenetrable Ciminian forest in the ninth book of the Ab urbe condita (9.36.1):

Silua erat Ciminia magis tum invia atque horrenda quam nuper fuere Germanici saltus, nulli ad eam diem ne mercatorum quidem adita.

In those days the Ciminian Forest was more impassable and appalling than were lately the wooded defiles of Germany, and no one - not even a trader - had up to that time visited it. ${ }^{75}$

And Florus did the same (Epit. 1.12.3):

Ciminius interim saltus in medio, ante invius plane quasi Caledonius vel Hercynius, adeo tum terrori erat, ut senatus consuli denuntiaret ne tantum periculi ingredi auderet.

Meanwhile the Ciminian forest, which lay between Rome and Etruria, and which was formerly as pathless as the Caledonian or the Hercynian forest, inspired such terror that the senate forbade the consul to venture to face its perils. ${ }^{76}$

Now the borders have been moved and are identified with Scottish Caledonia and the Germanic forests, but they still are characterised as impassable and unfamiliar. Through the Forest's depiction, Caesar thus mediated the relationship with the other - represented by Germanic peoples. Sallust wanted to underline the importance of North Africa; consequently, he adapted Thucydides' ethnogenesis on Sicily and framed it with common geographical considerations on the world's division into two or three areas. Moreover, he placed his narrative on the same level as the Punic Wars: yet, nearby the space of Carthage, he tries to depict Western Africa as the laboratory of the development of a new age of decadence. On his part, Livy took advantage of a Gallic invasion to remind his audience of the existence of an empire in Italy before the Roman domination, and, in this fifth book, which focuses on re-foundation, to replace the imperium Romanum for continual universal history. Yet, in the same way Strabo creates a focus on the Greek East and aligns himself intellectually with the world of Asia Minor. ${ }^{77}$ Livy only uses the geometrical vocabulary of the sci-

74 Clarke 1999, 204.

75 Translated by Foster 1926.

76 Translated by Foster 1929.

77 Clarke 1999, 243. 
entific geography (see angulum and circumcolunt) to refer to the Venetian shores, in order to stress an area of northern Italy, his region of origin. All these historians thus provide their audience with spaces that they can easily recognize and picture, in order to provide a global vision of the new Roman imperial world.

Therefore, it is no coincidence that one of the scarce commentaries on excerpts of historical works explicitly discusses the depiction of the battle in the Great Harbour of Syracuse by Thucydides, in ch. 7.71. Plutarch selected it because, in contrast with other passages of the Athenian historian, he believed that this description looked like a picture and that, through enargeia, Thucydides allowed the audience to experience the feelings of people who had seen or lived the event (Glor. Ath. 347a-c). Even if the Chaeronean author is writing at a later date, I still believe that his choice is emblematic of Roman expectations in the first century BCE. Such an experiment of clear and accessible depictions, with topical narrative frames and the guidance of the figure of an authoritative narrator/historian, could be presented to a broad audience.

In conclusion, I would like to go back to the opinion of N. Horsfall with which I began my paper: the researcher assumed that entertainment was chosen over instruction and accuracy. On the contrary, I tried to demonstrate that expectations existed towards precise geographical information in Rome in the first century BCE and that such accounts could be both instructive and pleasant. In fact, Roman audiences were of course eager to be told about the unknown territories and longed for marvellous depictions. A contemporary historian, Diodorus, hence offers to his Greek audience a survey of the paradoxa of the most remote parts of the oikoumene. ${ }^{78}$ Yet, at the same time, they also show a deep interest for the new world that had been built by the Roman conquests and most of all by the new ways of representing and looking at it. The generic difference with the poem of Propertius might help us to understand better the specific purpose of historiographical texts. It is typical of Augustan poetry, where enumerations of peoples and names of remote places can often be found as a means of underlining Rome's universal power and the part the princeps played in it. An ordinary citizen could use his imagination to discover and travel throughout the whole world, and universal space had thus become the frame for elegiac declarations of love. But, quite differently, ethno-geographical depictions were written by historians to understand better the new setting of the world. They no longer taught to the elite how to rule the empire; they rather offered to a broader audience debates and questions on the role that spaces had in the realisation of the Roman conquest and its future.

78 D.S. 3.18-48; see Baumann 2018. 


\section{Bibliography}

Arnaud, P. (2007), “Introduction. La géographie romaine impériale, entre tradition et innovation”, in: G. Cruz Andreotti / P. Le Roux / P. Moret (eds.), La invención de una geografía de la Península Ibérica, II La época imperial, Actas, 13-46.

Arnaud, P. (2009), "Texte et carte de Marcus Agrippa: historiographie et données textuelles", in: GeorgAnt 18, 57-110.

Aujac, G. (2001), Ératosthène de Cyrène, le pionnier de la géographie, Paris.

Baumann, M. (2018), "Wunderlektüren: Paradoxa und die Aktivität des Lesers in Diodorus Bibliotheke", in: T. Blank / F.K. Maier (eds.), Die symphonischen Schwestern. Narrative Konstruktion von ,Wahrheiten“ in der nachklassischen Geschichtsschreibung, Stuttgart, $227-240$.

Becker, T. (1900), “Weg und Gelände in der Sprache”, in: Zeitschrift für den deutschen Unterricht 14, 331-337.

Bickerman, E.J. (1952), “Origines Gentium”, in: CPh 47, 65-81.

Briquel, D. (1988), “Claude, érudit et empereur”, in: SAI 132, 217-232.

Briscoe, J. (2008), A Commentary on Livy. Books 38-40, Oxford.

Chevallier, R. (1986), "Les cartes dans les sources historiques romaines”, in: Caesarodunum 22, $158-166$.

Clarke, K. (1999), Between Geography and History: Hellenistic Constructions of the Roman World, Oxford.

Constans, L.A. (1926), César, La Guerre des Gaules, Paris.

Corbier, M. (2006), Donner à voir, donner à lire. Mémoire et communication dans la Rome ancienne, Paris.

de Franchis, M. (2012), “Tite-Live et l'habitant de Gadès (Pline le Jeune, Lettres, 2, 3, 8)”, in: P. Humel (ed.), De Fama, Études sur la construction de la réputation et de la postérité, Paris, $23-46$.

Engels, J. (2008), “Geography and History”, in: J. Marincola (ed.), A Companion to Greek and Roman Historiography, Malden, MA / Oxford, 541-552.

Feldherr, A. (2009), Spectacle and Society in Livy's History, Princeton.

Galinsky, K. (1996), Augustan Culture: An Interpretive Introduction, Princeton.

Harris, W.V. (1989), Ancient Literacy, Cambridge.

Horsfall, N. (1982), "The Caudine Forks: Topography and Illusion”, in: PBSR 50, 45-52.

Horsfall, N. (1985), “Illusion and Reality in Latin Topographical Writing”, in: G\&R, 32, 197-208.

Jacob, C. (1991), Géographie et ethnographie en Grèce ancienne, Paris.

Jaeger, M. (1997), Livy's Writen Rome, Ann Arbor.

Jauss, H.R. (1982), Toward an Aesthetic of Reception, transl. by T. Bahti, Minneapolis.

Ledentu, M. (2004), Studium scribendi. Recherches sur les statuts de l'écrivain et de l'écriture à Rome à la fin de la République, Louvain.

Levene, D.S. (2010), Livy on the Hannibalic War, Oxford.

Méry, L. (2012), "La carte et le territoire. Les excursus ethnographiques chez César et Salluste", in: M. Briand (ed.), La Trame et le Tableau. Poétiques et rhétoriques du récit et de la description dans l'Antiquité grecque et latine, Rennes, 139-154.

Miles, G.B. (1995), Reconstructing Early Rome, Ithaca.

Mineo, B. (2006), Tite-Live et l'histoire de Rome, Paris.

Moatti, C. (1997), La raison de Rome. Naissance de l'esprit critique à la fin de la République, Seuil.

Nicolet, C. (1988), L'inventaire du monde. Géographie et politique aux origines de l'empire romain, Paris. 
Ogilvie, R.M. (1965), A Commentary on Livy, Oxford.

Porte, D. (1993), Tombeaux romains. Anthologie d'épitaphes latines, Paris.

Rambaud, M. (1987), “L'espace dans le récit césarien”, in: Autour de César, textes de M.

Rambaud réunis par M. Bonjour et J.-C. Fredouille, Lyon, 273-289.

Rouveret, A. (1987), “Toute la mémoire du monde': La notion de collection dans la NH de Pline”, in: Helmantica 38, 115-133.

Sacks, K.S. (1990), Diodorus Sicilus and the First Century, Princeton.

Scheid, J. (2007), Res gestae divi Augusti, Paris.

Sherk, R.K. (1974), “Roman Geographical Exploration and Military Maps”, in: H. Temporini / W. Haase (eds.), Aufstieg und Niedergang der römischen Welt: Geschichte und Kultur Roms im Spiegel der neueren Forschung, II, 1, Berlin / New York, 534-562.

Syme, R. (1964), Sallust, Oxford.

Thomas, R.F. (1982) Lands and Peoples in Roman Poetry. The Ethnographical Tradition, Cambridge.

Trousset, P. (1993), "La frontière romaine et ses contradictions", in: La Frontière. Séminaire de recherche sous la direction d'Yves Roman, Lyon, 25-33.

Valette-Cagnac, E. (1997), La lecture à Rome, rites et pratiques, Paris.

Videau, A. (2000), “Mutations de l'auditoire à la charnière entre la République et l'Empire et décadence de l'éloquence selon Sénèque le Père", in: G. Achard / M. Ledentu (eds.), Orateurs, auditeurs, lecteurs. À propos de l'éloquence romaine à la fin de la République et au début du Principat. Actes de la table ronde du 31 janvier 2000, Paris, 91-101.

Walsh, P.G. (1961), Livy. His Historical Aims and Methods, Cambridge.

Walbank, F.W. (2002), Polybius, Rome and the Hellenistic World. Essays and Reflections, Cambridge.

White, H. (1973), Metahistory: The Historical Imagination in Nineteenth-Century Europe, Baltimore.

White, H. (1987), The Content of the Form. Narrative Discourse and Historical Representation, Baltimore.

Wiseman, T.P. (1979), Clio's Cosmetics: Three Studies in Greco-Roman Literature, Leicester.

Wiseman, T.P. (1981), "Practice and Theory in Roman Historiography”, in: History 66, 1981, $375-393$.

Woodman, A.J. (1988), Rhetoric in Classical Historiography. Four Studies, London.

Zanker, P. (1987), Augustus und die Macht der Bilder, Munich.

Zanker, P. (1991), “Immagini e valori collettivi”, in: A. Schiavone (ed.), Storia di Roma, II, 2, Turin, $193-220$.

Zanker, P. (2000), “Il mondo delle immagini e la comunicazione”, in: A. Giardina (ed.), Storia di Roma dall'antichità ad oggi. Roma antica, Bari, 211-245. 
